\title{
No polymorphisms in K13-propeller gene associated with artemisinin resistance in Plasmodium falciparum isolated from Brazzaville, Republic of Congo
}

Pembe Issamou Mayengue ${ }^{1,2^{*}} \mathbb{B}$, Roch Fabien Niama ${ }^{1,2}$, Dezi Kouhounina Batsimba ${ }^{1}$, Alida Malonga-Massanga ${ }^{1}$, Igor Louzolo², Nadia Claricelle Loukabou Bongolo², Lucette Macosso², Reyna Ibara Ottia,

Ghyslain Kimbassa Ngoma', Louis Régis Dossou-Yovo ${ }^{2,3}$, Brice Pembet Singana', Gabriel Ahombo',

Géril Sekangue Obili ${ }^{4}$, Simon Charles Kobawila ${ }^{1}$ and Henri Joseph Parra ${ }^{2}$

\begin{abstract}
Background: In the Republic of Congo, artemisinin-based combinations have been recommended for the treatment of uncomplicated malaria since 2006. However, the emergence of resistant parasites again these combinations in Southeast Asia is a threat for the control of this disease, especially in sub-Saharan Africa where the weight of the disease is important. Indeed, polymorphisms in Plasmodium falciparum K13-propeller gene have been involved in variations of drug sensitivity of Plasmodium falciparum to artemisinin-based combinations. The aim of the current study is to determine the prevalence of mutations of this gene in isolates collected in three health centers in Brazzaville.

Methods: From May 2015 to May 2016, a total of 131, 259 and 416 samples from patients with suspected malaria were collected at the Laboratoire National de Santé Publique, Hôpital de Mfilou, and the CSI «Maman Mboualé» respectively. After DNA isolation, genotyping and sequencing of Plasmodium falciparum K13-propeller were performed in positive Plasmodium falciparum isolates identified after msp-2 gene genotyping.
\end{abstract}

Results: All 806 samples collected were msp-2 genotyped and Plasmodium falciparum infections were confirmed in 287 samples with 43, 85, 159 samples from Laboratoire National de Santé Publique, Hôpital de Mfilou, and the CSI «Maman Mboualé» respectively. Of these 287 msp-2 positives samples, K13-propeller nested PCR products were successfully obtained from 145 (50.52\%) isolates and sequences were generated from 127(87.58\%) nested products. None of mutations that were associated with ACTs resistance in Southeast Asia were detected on the samples from three different study sites from Brazzaville. However, one mutation type was observed at position 578, where alanine was substituted by serine (A578S) in two isolates $(1.57 \%, 2 / 127)$, those from the Hôpital de Mfilou. No mutation was found in isolates from the two other sites.

Conclusion: The current study shows a very limited polymorphism in the K13-propeller gene in isolates from the Republic of Congo and K13 polymorphisms associate with ACT resistance are not present in this country. However, permanent and large surveillance of resistant parasite population using K13-propeller gene is recommended.

Keywords: Plasmodium falciparum, K13-propeller gene, Resistance, ACTs, Brazzaville, Republic of Congo

\footnotetext{
* Correspondence: pmayengue@yahoo.fr

${ }^{1}$ Faculté des Sciences et Techniques, Université Marien Ngouabi, BP 69,

Brazzaville, République du Congo

Laboratoire National de Santé Publique, BP 120, Brazzaville, République du

Congo

Full list of author information is available at the end of the article
}

(c) The Author(s). 2018 Open Access This article is distributed under the terms of the Creative Commons Attribution 4.0 International License (http://creativecommons.org/licenses/by/4.0/), which permits unrestricted use, distribution, and reproduction in any medium, provided you give appropriate credit to the original author(s) and the source, provide a link to the Creative Commons license, and indicate if changes were made. The Creative Commons Public Domain Dedication waiver (http://creativecommons.org/publicdomain/zero/1.0/) applies to the data made available in this article, unless otherwise stated. 


\section{Background}

In the Republic of Congo, malaria remains one of the main causes of consultation in health centers, with children under 15 years old and pregnant women being the most vulnerable groups $[1,2]$. Like in almost all sub-Saharan African countries, the high level of resistance of Plasmodium falciparum to chloroquine as well as the inefficacy of sulphadoxine-pyrimethamine and amodiaquine either singly or in combination for the treatment of uncomplicated malaria have led the Republic of Congo to change its anti-malarial drug policy for treating uncomplicated malaria to artemisinin-combination therapies (ACTs) in 2006 [3]. Previous studies have shown that ACTs remain highly efficacious in Sub-Saharan Africa, including the Republic of Congo [4-7]. However, the emergence of resistance to artemisinin derivatives, including ACTs in Southeast Asia is a serious public health concern. If resistance to ACTs may spread, particularly in sub-Saharan Africa, the public health implications could be disastrous, because no alternative drug is currently available with the same level of efficacy and tolerance than ACTs. In order to limit the development of Plasmodium falciparum resistance to current antimalarial, the World Health Organization (WHO) has recommended a vigilant surveillance of resistant parasites [8]. Recently, five principal mutations, namely the M476I, Y493H, I543T, R539T and C580Y in the Plasmodium falciparum Kelch propeller domain (K13-propeller) have been found to be associated with delayed parasite clearance after ACTs therapy in Cambodia [9]. Although no mutations associated with prolonged artemisinin clearance in Southeast Asia are found in sub-Saharan African regions, while diverse others mutations are identified even in isolates collected before or after the introduction of ACTs, regular surveillance is needed, taking into consideration the critical importance of ACTs in the control and elimination of malaria in these regions [10-14]. Thus, the current study aimed at measuring the prevalence of Plasmodium falciparum K13-propeller polymorphisms in clinical isolates collected from Brazzaville 10 years after the introduction of ACTs.

\section{Methods}

\section{Study areas and site preparation}

Brazzaville, the political capital hosts $38 \%(1,642,105$ inhabitants) of the total population of the Republic of Congo, estimated at 4312715 inhabitants. With the population expansion due to urbanization, Brazzaville is now divided into nine districts: Bacongo, Makelekele, Poto-Poto, Moungali, Ouenze, Talangaï, Mfilou, Madibou and Djiri. The present study was conducted in three health centers: Centre de Santé Intégré (CSI) « Maman Mboualé» located in the district of Talangaï, in the north part of city $\left(4^{\circ} 13^{\prime} \mathrm{S}, 15^{\circ} 17^{\prime} \mathrm{E}\right)$; Hôpital de Mfilou located in the district of Mfilou, in the south part of the city $\left(4^{\circ} 15^{\prime} \mathrm{S}, 15^{\circ} 13^{\prime} \mathrm{E}\right)$ and the Laboratoire National de Santé Publique (LNSP), the national reference laboratory located in the center part of city, in the district of Poto-Poto $\left(4^{\circ} 16^{\prime} \mathrm{S}, 15^{\circ} 15^{\prime} \mathrm{E}\right)$.

Malaria transmission in the study areas varies from low, moderate to intense with meso-, hyper- to perennial endemicity. Malaria infection is primarily due to $P$. falciparum. Two rainy seasons are observed each year with the main one during the months of February to May, and a short one from October to December [15].

In the early project stage, first, a meeting with the site actors including the head of each laboratory and microscopists was organized for the purpose of presenting the project objectives, methodology and expected results, as well as to obtain microscopists consent.

\section{Study population, blood samples and data collection}

From May 2015 to May 2016, patients with clinical signs of uncomplicated malaria, presenting at the laboratory of one of the three study sites were invited to participate in this study. Exclusion criteria comprised pregnancy, severe malaria or other severe illness as judged by the attending physician. A number of representative patients to be included each month, per week and per day has been estimated by the statistician taking into account the proportion of malaria reported in each health center, 1 year before starting the study. In sample size calculations, considering the proportion of malaria at $73.29 \%$ for the CSI « Maman Mboualé», 87.75\% for Hôpital de Mfilou and $2.33 \%$ for LNSP, using a confidence level of $95 \%$ and a marge error of $5 \%$, the SCHWARZ method [16] yielded a minimum number of 310, 200 and 100 patients to be recruited at the CSI « Maman Mboualé», Hôpital de Mfilou and the LNSP, respectively. Recruited patients were randomly selected from Monday to Friday. At the CSI « Maman Mboualé», a minimum of 7 patients were recruited per week, with at least one patient per day, whereas, at the Hôpital de Mfilou, the minimum number was 5 patients per week, with one per day. For the LNSP, 3 patients were enough, with one included on Monday, on Wednesday and on Friday. After informed consent was obtained, records were made on patient demographics, fever or history of fever in the last $48 \mathrm{~h}$, other signs of malaria, provenance, previous antimalarial drugs intake used of bed net treated. The axillary temperature was taken for fever confirmation.

At each study site, blood sample from each patient was blotted on the Whatman filter paper (3MM CHR) while preparing the thick blood smears, dried and transferred to the "Laboratoire National de Santé Publique" in Brazzaville, where isolation of deoxyribonucleic acid (DNA), polymerase chain reaction (PCR) and sequencing were performed. Before reading, thick blood smears were dried and stained with 10\% Giemsa solution (Sigma 
Chemical, Sigma Aldrich ChemieGmbh, Taufkirchen,

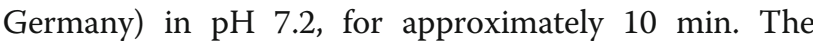
stain was gently washed away by adding drops of clean water and the slide was completely dried before examination. Thick blood smears were assessed by micrsocopists until 200 leucocytes had been counted. Parasite density was calculated for each patient assuming an average of 8000 leucocytes per $\mu \mathrm{l}$ of blood using the proposed method of the WHO [17]. Individual diagnostic result was given to each patient and advised to meet the prescribers for possible antimalarial chemotherapy.

\section{Extraction of parasite DNA}

Genomic DNA was extracted from samples collected on the Whatman filter paper by QIAamp DNA mini Kit (Qiagen, Hilden, Germany) according to the manufacturer's instruction. Briefly, 3 circles of approximately $3 \mathrm{~mm}$ diameter were punched out from a blood spot and placed into a $1.5 \mathrm{~mL}$ micro centrifuge tube in which $180 \mu \mathrm{L}$ of ATL buffer was added. Successive washing steps with AW1 buffer and AW2 buffer were followed by DNA elution with $150 \mu \mathrm{L}$ of $\mathrm{AE}$ buffer. Extracted DNA was stored at $-20{ }^{\circ} \mathrm{C}$ until use.

\section{Genotyping}

For multiple purposes, the highly polymorphic central region of Merozoite Surface Protein-2 (msp-2) gene was firstly genotyped as described previously [18], and positive Plasmodium falciparum samples were used for K13propeller genotyping. PCR amplification was performed following a 2-step amplification procedure in which the initial amplifications were followed by the nested PCR reactions using specific primers $\mathrm{K} 13-1$ and K13-4 for the first round and K13-inF2 and K13-inR2 for the nested PCR (Table 1), flanking the codons T474I, M476I, A481V, Y493H, T508 N, P527T, G533S, N537I, R539T, I543T, P553L, R561H, V568G, P574L, A578S, and C580Y; as described by Li et al. [12]. The amplification reactions were carried out as described by Ariey et al. [9]. For the first round, $1 \mu \mathrm{L}$ of DNA was amplified with $200 \mu \mathrm{M}$ of each deoxynucleotide triphosphate (dNTP), $1 \mu \mathrm{M}$ of each primer, $3 \mathrm{mM} \mathrm{MgCl}, 1.5$ units of Taq DNA polymerase and sterile ultrapure water to a final reaction of $25 \mu \mathrm{L}$. The mixtures were denatured at $95{ }^{\circ} \mathrm{C}$ for $5 \mathrm{~min}$, followed by 40 amplification cycles $\left(94^{\circ}\right.$
$\mathrm{C}$ for $30 \mathrm{~min}, 60{ }^{\circ} \mathrm{C}$ for $1 \mathrm{~min} 30 \mathrm{~s}$, and $72{ }^{\circ} \mathrm{C}$ for $1 \mathrm{~min}$ $30 \mathrm{~s}$ ), and final elongation at $72{ }^{\circ} \mathrm{C}$ for $10 \mathrm{~min}$. For the second round PCR, similar procedure with specific primers was used and $5 \mu \mathrm{L}$ of the first PCR product were used as template.

All PCR products were analyzed using 2\% agar gel electrophoresis. Thereafter PCR products were purified using PureLink ${ }^{\mathrm{TM}}$ Quick PCR Purification Kit (Invitrogen, by Thermo Fischer Scientific) and directly used as templates for DNA sequencing using an ABI 3500xL automated sequencer (Applied Biosystems Genetic Analyzer, HITACHI). The data was analyzed using Geneious 10.2.3 [19]. Mutations were assessed by comparing each sequence with the 3D7 K13-propeller (PF3D7_1343700) used as the reference.

\section{Data analysis}

Data were entered and verified in Microsoft Excel (Microsoft Corp., Seattle, USA) and validated in EpiInfo for Windows version 3.5.1. Data were analyzed using the SPSS 16.0 for Windows (Inc., Chicago, USA).The mutant and wild-type alleles identified in the analyzed isolates were used to generate the prevalence of the alleles.

\section{Results}

\section{Characteristics of febrile patients with symptoms of} malaria

A total of 131, 259 and 416 patients with suspected malaria were enrolled at the LNSP, Hôpital de Mfilou and the CSI «Maman Mboualé» respectively.

Out of 259 patients enrolled at the Hôpital de Mfilou, gender and age were recorded for 257 of them, while with regards to the CSI «Maman Mboualé», out of the 416 recruited patients, 410 had records on gender (Table 2).

All 806 samples collected were $m s p-2$ genotyped and Plasmodium falciparum infections were confirmed in 287 samples with 43, 85, 159 samples from LNSP, Hôpital de Mfilou, and CSI «Maman Mboualé» respectively. These $m s p$ - 2 positive samples were then considered for K13-propeller genotyping and nested PCR products was successfully obtained from 145 (50.52\%) isolates, with 5, 50 and 90 from LNSP, Hôpital de Mfilou, and CSI «Maman Mboualé» respectively (Table 3). K13-propeller sequences were generated from 127(87.58\%) nested

Table $1 \mathrm{~K} 13$ - propeller primers sequences

\begin{tabular}{ll}
\hline Primer name & Sequences \\
\hline K13-1(forward) & $5^{\prime} \ldots \ldots \ldots \ldots \ldots \ldots \ldots \ldots \ldots \ldots \ldots \ldots \ldots \ldots \ldots$ \\
K13-4 (reverse) & CGGAGTGACCAAATCTGGGA \\
K13-inF2 (forward) & GGGAATCTGGTGGTAACAGC \\
K13-inR2 (reverse) & TCAACAATGCTGGCGTATGTG \\
\hline
\end{tabular}


Table $\mathbf{2}$ Characteristics of patients

\begin{tabular}{llll}
\hline Characteristics & LNSP & Hôpital de Mfilou & CSI « Maman Mboualé» \\
\hline Total numbers & 131 & 259 & 416 \\
Gender (F/M) & $68 / 63$ & $131 / 126$ & $207 / 203$ \\
Median age (years) & $42(11-74)$ & $26(0.5-84)$ & $10(0.5-75)$ \\
$\begin{array}{l}\text { Groups of age (\%) } \\
\quad<5 \text { years }\end{array}$ & $0(0.0)$ & $38(14.8)$ & $99(23.8)$ \\
$\geq 5$ years & $131(100)$ & $219(85.2)$ & $317(76.2)$ \\
\hline
\end{tabular}

products (17 isolates did not generate good quality sequences that could be analyzed). To analyze polymorphisms in the K13-propeller, sequences alignment was done by comparing with the 3D7 strain (PF3D7_1343700).

None of mutations that were associated with ACTs resistance in Southeast Asia were detected on the samples from three different study sites from Brazzaville. However, one mutation type was observed at position 578, where alanine was substituted by serine (A578S). Only two isolates (with the frequency of $1.57 \%, 2 / 127$ ) had carried the A578S substitution, and those from the Hôpital de Mfilou. No mutation was found in isolates from CSI « Maman Mboualé » and LNSP.

\section{Discussion}

The present study of which all steps were carried out in Brazzaville, including K13-propeller sequencing, allowed us to analyze the polymorphism related to ACTs resistance in 127 Plasmodium falciparum isolates from Brazzaville. In the Republic of Congo, ACTs are recommended as first- and second-line treatment for uncomplicated malaria since 2006, and the efficacy of these combinations remains high as reported by Ndounga et al. $[5,6]$. However, it is important to monitor the eventual occurrence of the ACTs-resistant parasite population. The causes of the occurrence of resistance are multiple, including self-medication, which does increase drug pressure. Although the WHO recommendations require a preliminary parasitological test before taking any ACT, it is not surprising to notice the intake of these drugs without medical prescription in Brazzaville. Resistance to artemisinin and its derivatives is considered as major risk to public health, which would have a greater impact in sub-Saharan Africa where the burden remains high. The emergence of Plasmodium falciparum resistance to artemisinin and its derivatives, which appear as delayed parasite clearance after ACT treatment, has been reported in Southeast Asia [20]. At the molecular level, five major mutations in the Plasmodium falciparum K13-propeller gene, namely the M476I, Y493H, I543T, R539T, and C580Y mutations have been found to be associated with in vitro resistance to artemisinin and delayed parasite clearance following treatment with ACTs [9]. However, in the current study none of these mutations were found. Moreover, only a single limited A578S mutation has been found only in two isolates, all from Hôpital de Mfilou. A very low proportion of this A578S mutation has been also reported in Cambodia by Straimer et al. [21] and in many sub-Saharan countries such as Uganda, Mali, Equatorial Guinea, Kenya, Democratic Republic of Congo, and Ghana [10-12, 22-24].

The treatment outcomes and parasite clearance profiles for patients with A578S mutations in the current study were not evaluated. However, study conducted in Mali has shown that parasite clearance time was comparable between infections with non-synonymous K13-propeller mutations (including A578S mutation) and infections with the reference allele [11]. Thus, due to the common presence of this mutation in many countries, further characterization is needed as well as assessment of the role of this mutation in in vivo parasite clearance in others sub-Saharan Africa countries including the Republic of Congo is required.

Furthermore, the A557S mutation detected in the Republic of Congo by Taylor et al. [25] has not been detected in the current study. None of the 13 new mutations not associated with resistance to ACTs identified in the Republic of Congo by Koukouikila-Kousounda et al. [14] were also identified in the current study. Taking into account this large

Table 3 Identification of Plasmodium falciparum isolates and total number of K13-propeller sequence

\begin{tabular}{llll}
\hline Sites & Number of Plasmodium falciparum isolates & Number of K13 nested PCR & Number of K13-propeller sequence \\
\hline LNSP & 43 & $5(11.62 \%)$ & $3(60 \%)$ \\
Hôpital de Mfilou & 85 & $50(58.82 \%)$ & $48(96 \%)$ \\
CSI « Maman Mboualé » & 159 & $90(56.60 \%)$ & $76(84.4 \%)$ \\
Total & 287 & $145(50.52 \%)$ & $127(87.58 \%)$ \\
\hline
\end{tabular}


difference, repeated studies including different sites in all departments and increasing the number of isolates to be analyzed, are needed to better characterize the actual profile of polymorphisms in the K13- propeller gene in this country.

Although none of the mutations associated with artemisinin resistance in South-East Asia are present in sub-Saharan Africa including the Republic of Congo, new mutations are emerging on the African continent [26]. Thus, the impact of these mutations on resistance to ACTs is to be explored.

\section{Conclusion}

The current study shows very limited polymorphism in the K13-propeller gene in clinical isolates from the Republic of Congo and polymorphisms associate with ACTs resistance are not present in this country. Only one mutation type was observed at position 578 , where alanine was substituted by serine (A578S) in two isolates, those from the Hôpital de Mfilou. However, permanent and large surveillance of resistant parasite population using K13-propeller gene is recommended.

\footnotetext{
Abbreviations

ACTs: artemisinin-combination therapies; CERSSA: Comité d'Ethique de la Recherche en Sciences de la Santé; CSI: Centre de Santé Intégré; DNA: deoxyribonucleic acid; dNTP: deoxynucleotide triphosphate LNSP: Laboratoire National de Santé Publique; PCR: polymerase chain reaction; WHO: World Health Organization
}

\section{Acknowledgements}

We are grateful to all patients and all microscopists working in our three sites, who participated in this study. We thank also Professor Michael Ramharter for carefully reading of manuscript.

\section{Funding}

The study was supported by the "Laboratoire National de Santé Publique" and the World Academy of Sciences (RGA No.16-040 RG/BIO/AF/AC_IFR3240293321).

The "Laboratoire National de Santé Publique" has contributed in the design of the study, the collection, the analysis and interpretation of data; the World Academy of Sciences has contributed in the collection and analysis of samples as well as in writing the manuscript.

\section{Availability of data and materials}

The data generated and analyzed in this study are not publicly available for ethical reasons. However, they may be available from the corresponding author upon request.

\section{Authors' contributions}

PIM designed and coordinated field study, analyzed the data and wrote the draft of the article. RFN, DKB, IL, NCLB, LM, RIO, GKN, BPS, GA, GSO, SGK, HJP supervised field samples and data collection; LRDY participated in patients recruitment; AMM analyzed samples. All authors read and approved the final version and the final manuscript.

\section{Ethics approval and consent to participate}

The study was approved by the institutional "Comité d'Ethique de la Recherche en Sciences de la Santé" (№ 032/CERSSA-2015). Before the recruitment, the project objectives, methodology and expected results have been presented to patients and individual written consent was obtained. Individuals aged 18 years and above provided their own consent, while children and minors had their consent signed by their parents or guardians.
Consent for publication

Not applicable.

\section{Competing interests}

The authors declare that they have no competing interests.

\section{Publisher's Note}

Springer Nature remains neutral with regard to jurisdictional claims in published maps and institutional affiliations.

\section{Author details}

${ }^{1}$ Faculté des Sciences et Techniques, Université Marien Ngouabi, BP 69, Brazzaville, République du Congo. 'Laboratoire National de Santé Publique, BP 120, Brazzaville, République du Congo. 'Ecole Normale Supérieure, Université Marien Ngouabi, BP 69, Brazzaville, République du Congo. ${ }^{4}$ Centre Hospitalier Universitaire de Brazzaville, BP 1846, Brazzaville, République du Congo.

Received: 3 July 2018 Accepted: 19 October 2018

Published online: 29 October 2018

\section{References}

1. Ministry of Health and Population. Programme Biennal de Développement Sanitaire 2015-2016. Ministère de la Santé et de la Population, Brazzaville, République du Congo. 2014

2. Mbongo JA, Ekouya BG, Koulimaya GC, Iloki L. Paludisme Congénital au Centre Hospitalier et Universitaire de Brazzaville : une Étude Épidémiologique de 90 Cas. Health Sci Dis. 2015;16:1-4.

3. Ministry of Health and Population. Politique nationale de lutte contre le paludisme. Ministère de la Santé et de la Population, Brazzaville, République du Congo. 2006. Accessed 4 May 2018.

4. Ndounga M, Tahar R, Casimiro PN, Loumouamou D, Basco LK. Clinical efficacy of artemether lumefantrine in Congolese children with acute uncomplicated falciparum malaria in Brazzaville. Malar Res Treat. 2012;2012:749479.

5. Ndounga M, Mayengue PI, Casimiro PN, Loumouamou D, Basco LK, Ntoumi F, Brasseur P. Artesunate-amodiaquine efficacy in Congolese children with acute uncomplicated falciparum malaria in Brazzaville. Malar J. 2013;12:53.

6. Ndounga M, Mayengue PI, Casimiro PN, Koukouikila-Koussounda F, Bitemo M, Matondo DB, Ndounga DLA, Basco LK, Ntoumi F. Artesunateamodiaquine versus artemether-lumefantrine for the treatment of acute uncomplicated malaria in Congolese children under 10 years old living in suburban area: a randomized study. Malar J. 2015;14:423.

7. Singana BP, Bogreau H, Matondo BD, Dossou-Yovo LR, Casimiro PN, Mbouka R, Ha Nguyen KY, Pradines B, Basco LK, Ndounga M. Malaria burden and antimalarial drug efficacy in Owando, northern Congo. Malar J. 2016;15:16.

8. World Health Organizaion. Malaria report. Geneva: World Health Organization; 2015.

9. Ariey F, Witkowski B, Amaratunga C, Beghain J, Langlois AC, Khim N, et al. A molecular marker of artemisinin-resistant Plasmodium falciparum. Nature 2014;505:50-5.

10. Conrad MD, Bigira V, Kapisi J, Muhindo M, Kamya MR, Havlir DV, et al. Polymorphisms in K13 and falcipain-2 associated with artemisinin resistance are not prevalent in Plasmodium falciparum isolated from Ugandan children. PLoS One. 2014;9:e105690.

11. Ouattara A, Kone A, Adams M, Fofana B, Maiga AW, Hampton S, et al. Polymorphisms in the K13-propeller gene in artemisinin-susceptible Plasmodium falciparum parasites from Bougoula-Hameau and Bandiagara, Mali. Am J Trop Med Hyg. 2015;92:1202-6.

12. Li J, Chen J, Xie D, Eyi UM, Matesa RA, Ondo Obono MM, et al. Limited artemisinin resistance-associated polymorphisms in Plasmodium falciparum K13-propeller and PfATPase6 gene isolated from Bioko Island, Equatorial Guinea. Int J Parasitol Drugs Drug Resist. 2016;6:54-9.

13. Mita T, Culleton R, Takahashi N, Nakamura M, Tsukahara T, Hunja CW, et al. Little polymorphism at the K13 propeller locus in worldwide Plasmodium falciparum populations prior to the introduction of artemisinin combination therapies. Antimicrob Agents Chemother. 2016;60:3340-7.

14. Koukouikila-Koussounda F, Jeyaraj S, Nguetse CN, Nkonganyi CN, Kokou KC, Etoka-Beka MK, et al. Molecular surveillance of Plasmodium falciparum drug resistance in the republic of Congo: four and nine years after the introduction of artemisinin-based combination therapy. Malar J. 2017;16:155. 
15. Ntoumi F, Vouvoungui JC, Ibara R, Landry M, Sidibé A. Malaria burden and case management in the republic of Congo: limited use and application of rapid diagnostic tests results. BMC Public Health. 2013;13:135.

16. Schwartz D. Méthodes statistiques à l'usage des médecins et des biologistes /Troisième édition. Paris: Flammarion Médecine-sciences. 1969; ISBN-2-25730326-1; http://www.sudoc.fr/005623065.

17. World Health Organization. Bench aids for malaria Microscopy. Geneva. 2009; ISBN-13 9789241547864.

18. Mayengue PI, Ndounga M, Malonga FV, Bitemo M, Ntoumi F. Genetic polymorphism of mérozoïte surface protein-1 and merozoite surface protein-2 in Plasmodium falciparum isolates from Brazzaville, republic of Congo. Malar J. 2011;10:276.

19. Kearse M, Moir R, Wilson A, Stones-Havas S, Cheung M, Sturrock S, et al. Geneious basic: an integrated and extendable desktop software platform for the organization and analysis of sequence data. Bioinformatics. 2012;28:1647-9.

20. Dondorp AM, Nosten F, Yi P, Das D, Phyo AP, Tarning J, et al. Artemisinin resistance in Plasmodium falciparum malaria. J Trop Med. 2009:5:455-67.

21. Straimer J, Gnadig NF, Witkowski B, Amaratunga C, Duru V, Ramadani AP, et al. Drug resistance K13-propeller mutations confer artemisinin resistance in Plasmodium alciparum clinical isolates. Science. 2015;347:428-31.

22. Muwanguzi J, Henriques G, Sawa P, Bousema P, Colin J, Sutherland Beshir K. Lack of K13 mutations in Plasmodium falciparum persisting after artemisinin combination therapy treatment of Kenyan children. Malar J. 2016;15:36.

23. Makaba MD, Kayembe M, Situakibanza HT, Bobanga LC, Nsibu GN, Mvumbi $P$, et al. Falciparum malaria molecular drug resistance in the Democratic Republic of Congo: a systematic. Malar J. 2015;14:354.

24. Feng J, Li J, Yan H, Feng X, Xia Z. Evaluation of antimalarial resistance marker polymorphism in returned migrant workers in China. Antimicrob Agents Chemother. 2015;59:326-30

25. Taylor SM, Parobek CM, DeConti DK, Kayentao K, Coulibaly SO, Greenwood $\mathrm{BM}$, et al. Absence of putative artemisinin resistance mutations among plasmodium falciparum in sub-Saharan Africa: a molecular epidemiologic study. J Infect Dis. 2014;211:680-8.

26. Conrad MD, LeClair N, Arinaitwe E, Wanzira H, Kakuru A, Bigira V, et al. Comparative impacts over 5 years of artemisininbasedcombination therapies on Plasmodium falciparum polymorphismsthat modulate drug sensitivity in Ugandan children. J Infect Dis. 2014;210:344-53.

Ready to submit your research? Choose BMC and benefit from:

- fast, convenient online submission

- thorough peer review by experienced researchers in your field

- rapid publication on acceptance

- support for research data, including large and complex data types

- gold Open Access which fosters wider collaboration and increased citations

- maximum visibility for your research: over $100 \mathrm{M}$ website views per year

At $\mathrm{BMC}$, research is always in progress.

Learn more biomedcentral.com/submissions 